\title{
InfoNorth
}

\section{The Muskox Patrol: High Arctic Sovereignty Revisited}

\section{by Peter Schledermann}

$\mathrm{T}$ The role of the Royal Canadian Mounted Police (RCMP) in the Canadian government's quest to secure international recognition of its claims to sovereignty over the High Arctic islands is a chapter of Canadian history rarely visited. Yet the sovereignty battle over a group of Arctic islands few can even name was the stuff of high-stakes political poker: bluff indifference mixed with sudden bursts of national interest, courage, hardships, and dedication of a high order. Canadian government activities in the High Arctic between 1900 and 1933 were carried out almost exclusively in response to the real or perceived intentions of other nations to challenge Canada's sovereignty claims. This story is currently being presented as a proposal for a documentary film, "The Muskox Patrol," by Ole Gjerstad and Peter Schledermann.

For 11 years, between 1922 and 1933, a small group of dedicated RCMP officers and their Native assistants had served to safeguard Canadian sovereignty against claims by foreigners to the High Arctic islands. Theirs had been the coldest, most precarious beat of policemen anywhere. "The Muskox Patrol" is the story of the complex web of political events that culminated in sending the Mounties to the High Arctic. Perhaps surprisingly, the connecting thread in the web turned out to be muskoxen.

For the first two decades following the 1880 transfer of the Arctic islands from Great Britain to Canada, Ottawa paid scant attention to the legality of the possession. The first jolt to the government's complacency was delivered from Norway, soon after Otto Sverdrup's successful completion of the second Norwegian Fram Expedition to the High Arctic islands (1898-1902). In 1898, when severe ice conditions in Kane Basin prevented Sverdrup from carrying out his original plan to round the northern reaches of Greenland, he had decided to carry out extensive surveys, scientific studies, and mapping of many of the High Arctic islands (Sverdrup, 1903). On 9 May 1900, Sverdrup recorded that he and the expedition geologist, Ivar Fosheim, had reached $80^{\circ} 55^{\prime} 16^{\prime \prime} \mathrm{N}$, the northern end of a large island they named Axel Heiberg Island. They built a small cairn, in which Fosheim planted the Norwegian flag, while Sverdrup wrote a report of the expedition and, in the name of the King, proclaimed possession for Norway of all the territory they had covered during the expedition. The message, signed by both men, was placed in an empty cognac bottle (Fosheim, 1994:128).
Under Sverdrup's hugely successful leadership, members of the Norwegian expedition spent four years mapping and surveying large, often unknown portions of the High Arctic islands. The only people they encountered were North Greenlandic Inughuit who had crossed Smith Sound to assist the American explorer Robert Peary in his quest to reach the North Pole. When the expedition returned to Norway in 1902, Sverdrup began what would become a lifelong, personal struggle to press his government into pursuing the claim he had set in motion. While the Norwegian government expressed little official interest in the matter, the Dominion of Canada government took the claim far more seriously. For centuries, American and European whalers and explorers had frequented Arctic waters at will, living off the land and the seas as they saw fit, even operating land-based stations when it was convenient. Occasional protests by the Hudson's Bay Company had been ignored.

Adding urgency to dealing with Sverdrup and possible Norwegian territorial interests were reports that another Norwegian explorer, Roald Amundsen, without acknowledging Canadian territoriality, was setting out on what would prove to be the first successful navigation by Europeans of the Northwest Passage.

Following the unfortunate outcome of the Alaska boundary settlement with the United States, the Canadian government realized that historical paper claims to land were a poor substitute for effective occupation (Judd, 1969:594). The 1903 establishment of police authority on Herschel Island in the western Arctic was to be followed by extension of similar authority to the central and eastern Arctic. In the spring of 1903, the Neptune expedition sailed north under the command of A.P. Low (Ross, 1976). Onboard was Major (later Superintendent) J.D. Moody, heading a six-man detachment of the RCMP. The old, 465-ton wooden sealer Neptune, under Captain S.L. Bartlett, visited whaling stations in Cumberland Sound before heading into Hudson Bay, where the expedition wintered in Fullerton Harbour near Captain Comer's whaling ship Era. The whaling industry was in sharp decline, resulting, as Moody observed, in increasing trade with the local population. Muskox skins were high on the wanted list. Much to the dismay of Captain Comer, Moody, apparently on his own initiative, issued a proclamation forbidding the killing of muskoxen or trading skins from the Natives (Ross, 1984). 
In 1904, the Neptune sailed north to Cape Herschel on Ellesmere Island and later into Lancaster Sound and Pond Inlet. Whenever whalers were encountered, Moody impressed upon them the Canadian government's intention to actively enforce regulations and restrictions on their operations. The Canadian flag was being planted in the eastern Arctic.

By the time the Neptune headed south, the Canadian government had already planned the next "sovereignty expeditions" into the Arctic. A German-built vessel, Gauss, had been acquired and renamed the C.G.S. Arctic. Joseph Bernier, chosen to command the expedition, had already made clear his interest in Arctic exploration in 1898, when he presented plans for a North Pole expedition to the Quebec Geographical Society. Although his North Pole plans never materialized, Bernier would play an impressive role in Canada's quest to secure its Arctic sovereignty claim (Dorion-Robitaille, 1978).

In 1904, the Arctic entered Hudson Bay on the first of four extensive voyages into the Arctic islands. On subsequent voyages, Captain Bernier, government officials, and police officers travelled throughout the Arctic islands, placing official Canadian declarations of possession in large stone cairns. Occasionally they replaced documents left by Sverdrup (Bernier, 1909). In Norway there was some public support for acting on Sverdrup's claim, but the government in Oslo showed little interest in pursuing the matter. As the years went by, the High Arctic sovereignty issue had become a personal quest for Bernier, just as pushing the Norwegian claim had become a life's struggle for Sverdrup.

While Bernier was securing Canada's sovereignty claims in the eastern Arctic, Vilhjalmur Stefansson was busy in the western Arctic. Between 1913 and 1917, he set out on several expeditions into the western High Arctic islands as part of the Canadian Arctic Expedition (Taylor, 1955). On 15 June 1916, he erected a cairn on Meighen Island. On 20 July 1916, Stefansson and his party reached the southeastern tip of Ellef Ringnes Island, where he found a message left only a few months earlier by the American explorer Donald MacMillan (1918), who had journeyed westward from Etah, Greenland, as part of his American Crocker Land Expedition (1913-17). MacMillan's expedition relied heavily on the hunting of muskoxen, undoubtedly a factor in the Canadian government's 1917 decision to add a new clause to the Northwest Game Act. The clause stated that killing muskoxen was prohibited except for Native inhabitants, and for them only to prevent starvation (Dick, 2001:273).

With the amendment to the Game Act in place, High Arctic sovereignty concerns gradually slipped off the Canadian government's agenda until January 1920, when Captain Comer, appearing before a Royal Commission in Ottawa, reported that he had observed 150 dried muskox skins at Knud Rasmussen's trading post at Thule (Barr, 1991:86). The Thule mission and trading station essentially owed its origin to Robert Peary. Following his pronouncement of having reached the North Pole in the spring of 1909, Peary left North Greenland and a population of Inughuit who had come to rely heavily on the firearms, ammunition, and other Western goods that Peary had provided for over a decade as payment for their services. It would be up to Knud Rasmussen and Peter Freuchen to fill the gap by establishing a mission and trading station in North Star Bay. The "Thule station" was in full operation by 1910 (Gilberg, 1976). The muskox skins Comer had referred to had been obtained from hunting trips on Ellesmere Island by Inughuit from North Greenland, in violation of the Canadian government's prohibition on killing muskoxen on Canadian territory except for food in case of emergency. Comer's report was later confirmed by MacMillan, who mentioned that Smith Sound Eskimos annually visited Ellesmere Island for polar bear and muskox hunting.

Ottawa sent a notification of protest to the Danish Government, which pointed out that North Greenland was not under Danish administration: with the establishment of the Thule Station in 1910, Knud Rasmussen had become the sole figure of authority in North Greenland. When correct channels of communication were established, Knud Rasmussen's written response to Ottawa's inquiry caused great alarm. In his long and thoughtful letter, Rasmussen pointed out that American expeditions had hunted caribou to near extinction in North Greenland, forcing Inughuit to hunt muskoxen for fur and meat. Rasmussen ended his letter with a statement that brought a startled J.B. Harkin, Director of the Dominion Parks Branch, Department of the Interior, into action:

It is well known that the territory of the Polar Esquimaux falls within the region designated as "no man's land" and there is therefore no authority in the district except that which I exercise through my station - an authority which I have hitherto had no difficulty in maintaining chiefly because the Polar Esquimaux, when reasonably treated, adopt a very rational attitude toward all decisions which the station considers it advisable to take...Fully conscious of the work which is ahead and of the responsibility I assume, I venture to close with the observation that, in order to carry out the protective measures indicated in this statement, I shall need no assistance whatever from the Canadian Government. (Barr, 1991:89)

Harkin informed both the Danish government and Knud Rasmussen that Canada would take a strong stand to demonstrate its exclusive ownership of Ellesmere Island and territories west. If necessary, the sovereignty issue would be enforced by the establishment of RCMP posts on Ellesmere Island. As part of the government's "renewed" sovereignty initiatives, RCMP Staff Sergeant A.H. Joy was sent to Pond Inlet with the Hudson's Bay Company supply ship Baychimo to investigate, arrest, and prepare trial proceedings against Inuit hunters accused of murdering a trader named Robert Janes (Grant, 2002). 
In July 1922, Captain Bernier brought the Arctic north, loaded with building materials, supplies, and men to be stationed in some of the most remote outposts in the far North, lands that had not been occupied by Inuit for several hundred years. With heavy ice and bad weather preventing an immediate landing at Pond Inlet, where one of the stations was to be erected, Bernier stopped at Saanirut (Button Point) on Bylot Island, where a meeting was arranged with Staff Sergeant Joy. An Inuit family from Pond Inlet agreed to accompany the RCMP officers to a post yet to established and remain for their first wintering. With Kakto (Qattuuq), his wife, Ooralloo, (Ulaajuq) and their four children, the Arctic headed for the southeast coast of Ellesmere Island (Lee, 1928:26). Difficult ice conditions precluded attempts to reach Sverdrup's 1900 01 wintering place in Fram Fjord, on the south coast of Ellesmere Island, which ironically had been chosen in Ottawa as a good location for a post because of Sverdrup's favourable report of the area. The search for an alternative place to establish the detachment was finally narrowed to a small valley opposite Smith Island. The post was named Craig Harbour after the commander of the expedition, J.D. Craig, who represented the Department of the Interior. Construction of the detachment houses was soon under way. A small shack had been prepared for Kakto and his family.

In his excellent book Policing the Top of the World, Constable Herbert Patrick Lee (1928) describes the hurried effort to land all supplies and erect the detachment buildings at Craig Harbour while Captain Bernier kept an anxious eye on the gathering pack ice.

For six days we toiled without a let-up. The ship could not stay long. It was now the 21 st of August and already the ice masses pouring down the Sound from the west menaced the ship. It was a relief to get the 125 tons of sacked coal ashore. Then, while a party headed by the ship's carpenter worked erecting the buildings, the rest of us toiled frantically to load the boats and get the supplies ashore. Everything depended on speed...by the morning of the sixth day the last boat-load of stores was landed...Late on the 28th of August the line of floes crept down on the ship and forced the Captain to raise anchor and keep the vessel moving to evade being crushed. ...It was a cold, bitter evening and the mist rising from the bay obscured the midnight sun and cast an eerie gloom over the harbour. The warm glow thrown up by the "Arctic's" hatchway never looked more homelike as we stood with fur caps over our ears and peajackets drawn up about our necks...At midnight Inspector Wilcox and I stepped into the waiting whale-boat and bade our friends of "Arctic" good-bye. "Take care of yourselves. We'll see you next year," shouted Captain Bernier from the bridge... when morning came we would be alone-a small party of seven men, the sole inhabitants excepting a single Eskimo family of a million square miles of Arctic wilderness. (Lee, 1928:35-36)
Assisting the seven officers must not have been an easy task, especially for Ooralloo, who made winter clothing for everyone. In July 1923, calamity struck the Inuit family when two of their children, within a few days of each other, died of influenza (Lee, 1928:100).

Serving as protectors of the High Arctic presented many dangers, and fire was among the greatest. Three officers, Constables Lee and Anstead and Corporal Michelson, were stationed at Craig Harbour during the second wintering, assisted by Panikpa and Klishoo and their families from North Greenland. That winter could easily have been fatal for the officers. The first near-disaster occurred on a bitterly cold afternoon, when heat from the stove in the main house caused the burlap inner lining of the ceiling to catch fire. Lee, Anstead, and Michelson battled furiously to put the fire out.

Outside the blizzard was blowing...we flew to the fire extinguishers... only to find them frozen and useless. We had no water in the house except a half-empty bucket of slops... Snatching up a fur coat, Anstead dashed out into the blinding drift...how he found his way through the storm I don't know, but he reached the blubber-shed and roused the Eskimos... When Anstead returned with an axe we managed to cut a hole in the roof...It was hopeless. The shack was doomed and the only thing we could do was to save what we could. (Lee, 1928:191-192)

The desperate men saved their bedding, rifles, one case of ammunition, and some personal belongings. The Inughuit worked heroically, all frost-bitten. Lee noted that the next day was clear and cold. The mercury on the outside thermometer was stuck at $55^{\circ}$ below zero. Where the house had been, only the shell of the outer snow-wall remained.

The second time danger struck, the three officers were nearly killed from carbon monoxide poisoning. In the blubber shed, they had jury-rigged a cooking stove to get some heat. During the day all seemed well. Lee was the last to turn in, but when he lay down on the bunk he felt poorly. About to put out the candle, he noticed that the flame was very dim. Weakly he jumped down from the bunk and headed for the door-fell heavily against it, and tumbled outside. The sound of the crash woke Anstead, and both he and Michelson managed to get outside. Gas, formed when the coal stove was banked up for the night, had been seeping out into the little shed. As Lee points out, it had been a close call (Lee, 1928:196).

Lee's (1928) account shows how much the presence of Inuit families at the detachments meant to the RCMP officers in the High Arctic. Many of the young constables learned to communicate tolerably well in Inuktitut. People like Panikpa and Nookapingwa, who had assisted MacMillan and Peary, filled many an evening with their accounts of long, dangerous journeys. Having families and kids around brought some element of normality to the lives of the young men from the South. 


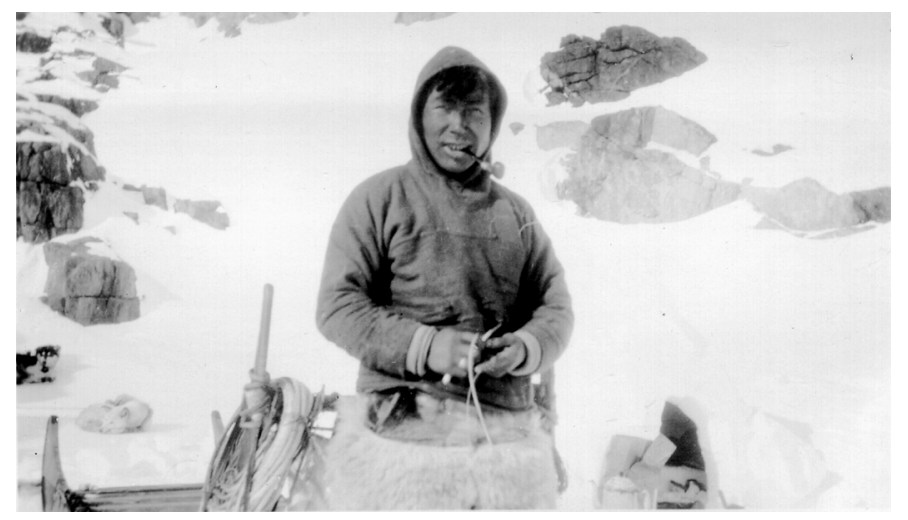

Nookapingwa (H.W. Stallworthy Collection, AINA).

From the outset, it had been the government's objective to establish a detachment on the shores of Bache Peninsula, at the entrance to Flagler Bay. The bay was the primary route of travel to Sverdrup Pass, gateway to the west side of Ellesmere Island and good muskox hunting. Ice conditions in Buchanan Bay proved to be a considerable obstacle. In 1924, the Arctic made several unsuccessful attempts to reach the chosen location, and all station supplies were finally cached on the shores of Sverdrup's 1898-99 winter harbour, Fram Havn. A small hut was erected, with a signboard proclaiming the presence of the Kane Basin RCMP Detachment. Part of the hut is still standing, with the signboard barely readable.

The Arctic proceeded to the south coast of Devon Island, where the Dundas Harbour Detachment (initially also known as the Bernier Detachment) was established. The Dundas Harbour post was to have a long and sometimes troubled history, both as an RCMP post and later as a trading station. Two RCMP officers lie buried in a fenced-in cemetery plot on a small terrace in the cliffs above the station buildings. Constable Maisonneuve committed suicide while camping alone in nearby Croker Bay, and Constable Stephenson accidentally shot himself while hunting (S. Hamilton, pers. comm. 2002).

Another unsuccessful attempt to reach the proposed Bache post location was made in 1925. Finally, in late summer of 1926, Captain E. Falk managed to load all the goods from Fram Harbour onboard the Beothic and transport everything to the Bache post location. The official opening of the Bache post took place on August 9. Present at the opening were Constables Dersch, Makinson, and Garnet; Corporal Friel; Sergeant Joy; Inspector Wilcox; George P. Mackenzie (commander of the Eastern Arctic Expedition - 1926); Dr. Leslie D. Livingstone (medical officer); Dr. L.J. Weeks (geologist); Captain Falk; Maurice Haycock (geologist and artist); and the Greenlandic Inughuit assistants, Nookapingwa, Oodee, and Ahkeeoo.

The annual supply ship's approach to the Bache Post was never easy-and often impossible, with ice blocking the way. In many years, the station personnel had to travel at least $40 \mathrm{~km}$ out to Fram Harbour to meet the ship, unload supplies, and transport them by boat or sleds back to the

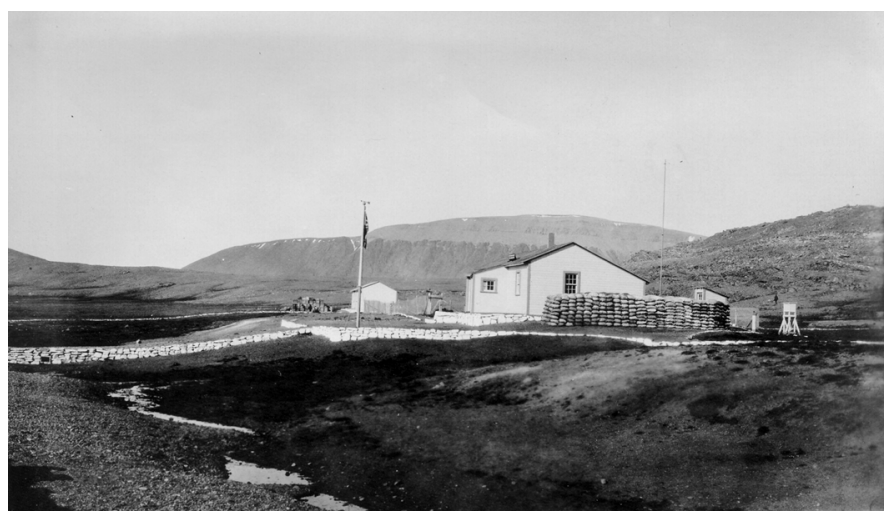

Dundas Harbour RCMP Detachment in 1933. (H.W. Stallworthy Collection, AINA).

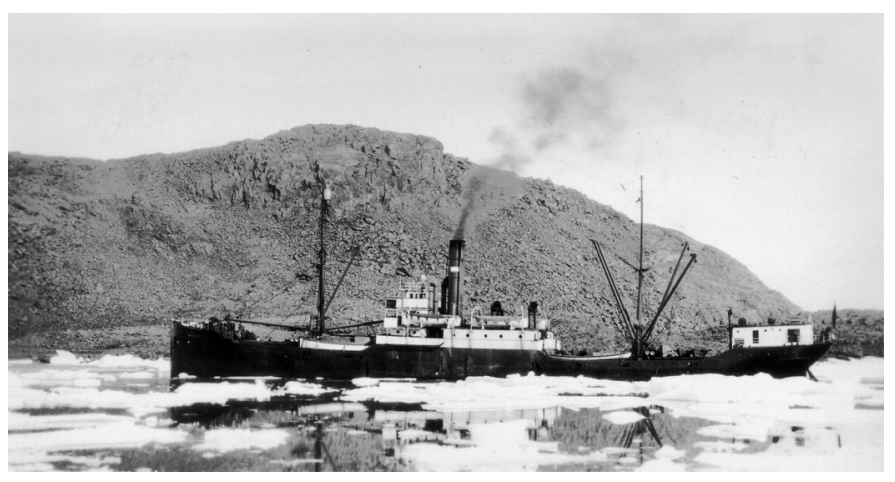

The Beothic enters Fram Harbour in 1930. (H.W. Stallworthy Collection, AINA).

station. The boat transport of supplies back to the station rarely lacked dangerous moments from encounters with fast-moving drift ice and walrus.

Detachment duties included long sled patrols to ensure that Canadians could claim to have set foot on the High Arctic islands. Hunting trips were frequently made in the spring to secure food for everyone at the detachments, including the dogs (Lee, 1928). The sled trips were also a welcome break from cramped quarters and inactivity during the darkest winter months.

The year-end report of the Royal Canadian Mounted Police for 1929 describes one of these amazing journeys by Inspector A.H. Joy. Together with Constable Taggart, Nookapingwa, and two dog teams, the party travelled 1700 miles from Dundas Harbour to Winter Harbour on Melville Island, then eastward to the Bache Peninsula by way of Lougheed, King Christian, Ellef Ringnes, Cornwall, and Axel Heiberg Islands (RCMP, 1929).

Among the many Inughuit assistants who served with the RCMP in the High Arctic, the name Nookapingwa is very prominent. His long service with the RCMP on Ellesmere Island, including the extremely trying 1932 Krüger search expedition, was exemplary. Few of the longer sled patrols took place without him, and he served practically throughout the entire first period of the RCMP presence in the High Arctic between 1924 and 1933. 


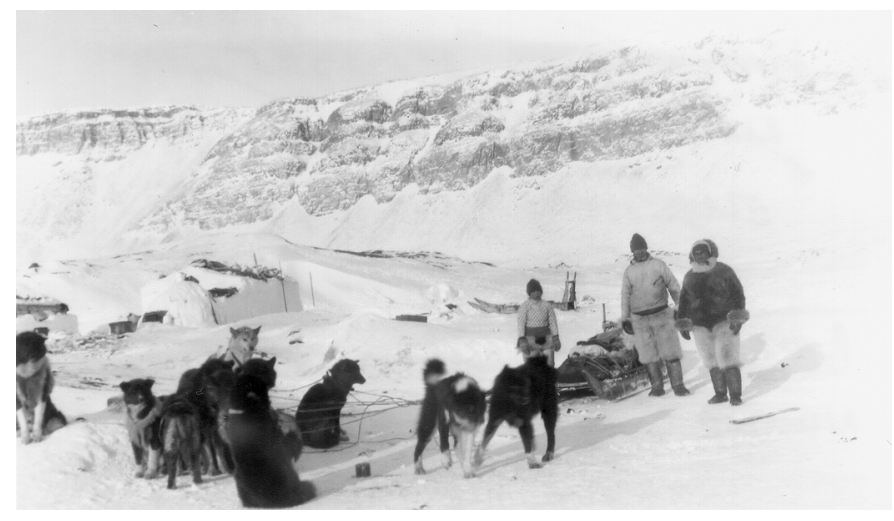

Search parties leaving the Bache post in 1932 (from right to left: Nookapingwa, Inuetuk, and a young boy). (H.W. Stallworthy Collection, AINA).

On 12 March 1930, the German scientist and explorer, Dr. H.K.E. Krüger, arrived at the Bache post from Greenland, with a licence to enter the NWT. The main party consisted of Krüger, Åge Rose Bjare, and the Inughuit hunter Akqioq. The three men were last seen by members of their returning support party on Axel Heiberg Island in 1930 (Barr, 1993).

In the spring of 1931, Stallworthy, accompanied by Nookapingwa and Inuetuk, set out to search for the missing party, but their attempt to reach Axel Heiberg Island was abandoned because of poor sledding conditions. They returned to the Bache post and headed south to Craig Harbour, only to find that no one had been there since the previous year. They returned to Bache and began to prepare for the closure of the post and the arrival of the Beothic, which was supposed to return the Inughuit to Greenland and the officers south. In August, everyone from the Bache Post travelled out to Fram Harbour to meet the Beothic. Excitement was high when the ship arrived on the $12^{\text {th }}$, but dampened when Inspector Joy announced that, since the Krüger party was still missing, the Bache post would remain open for another year. A final search for Krüger was planned for the spring of 1932. The change of plans must have been greeted with mixed emotions and serious concerns about obtaining enough food for both men and dogs. For Stallworthy, the new orders meant that his marriage plans had to be postponed.

On 20 March of that year, eight teams, totalling 124 dogs, left the Bache post (Stallworthy, 1932). Once the party reached the west side of Ellesmere Island, Corporal Stallworthy headed north, accompanied by Eetookashoo, Kahdi (Robert Peary's son), and Quavigarsuaq. Corporal Hamilton, Nookapingwa (spelled "Nookapinguaq" by Stallworthy), and Kahkacho headed south, accompanied for a short time by Inuetuk and Seekeeunguaq (Nookapingwa's son). With food running low, Stallworthy (1932) reluctantly gave permission for the Inuit to kill some of the many muskoxen they were seeing almost daily. In his official report, typed out at the Bache post on 25 June 1932, he expressed his regret at having been in a position where it became necessary to kill the animals.

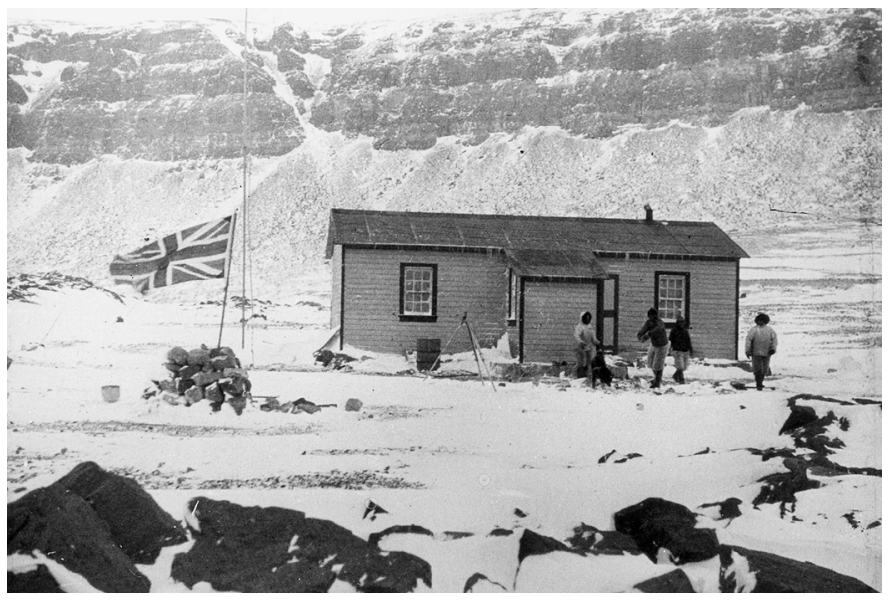

The abandoned Bache post in 1935, when visited by members of the British Oxford Expedition. (H.W. Stallworthy Collection, AINA).

On 10 April, with the invaluable help of Eetookashoo, who had been in the area with Frederick Cook and later with Donald MacMillan, Stallworthy located an old cairn built by Peary opposite Cape Thomas Hubbard on the north shore of Axel Heiberg Island. In the cairn, Stallworthy found the first trace of the Krüger expedition: a message the party had left on 24 April 1930. According to the note, they were planning to head west toward Meighen Island. Lack of food prevented Stallworthy and his men from attempting to reach Meighen Island. In his report, Stallworthy provides a clear picture of the hardships faced by the RCMP search expedition.

On April 20th, after a 43 hour almost continuous march we were only about 15 miles short of Cape South West, during this march we had fed our spare seal skins, mitts and foot wear to the dogs...The Cape, where we knew the cache was, was in plain view, but we had not the strength to get there without a rest. We built an igloo here, killed 4 native and 2 police dogs to feed to the others.

In 1957, Dr. Raymond Thorsteinsson of the Geological Survey of Canada located on Meighen Island what must have been the last message by Krüger. The message had been placed in a cairn built by Stefansson's party in 1916 (Barr, 1993).

Our Muskox Patrol story ends with the closing of the Bache Detachment in 1933. Three years before that, in the late fall of 1930, Dr. O.D. Skelton, Canadian Under Secretary of State for External Affairs, had concluded a long negotiation with Otto Sverdrup and the Norwegian Government. Sverdrup received $\$ 67000$ dollars as payment for his maps, records, and observations made during the Fram expedition, and Norway agreed not to pursue its claim to the Arctic islands (Fairley, 1959). Otto Sverdrup died only a few weeks after the offer was accepted.

Canada's concerns about the legality of its sovereignty claim to the High Arctic did not end there. However, the 
immediate challenge had been dealt with effectively through the huge efforts of the RCMP personnel and their Inughuit assistants from Greenland.

\section{REFERENCES}

BARR, W. 1991. Back from the brink: The road to muskox conservation in the Northwest Territories. Komatik Series 3. Calgary, Alberta: The Arctic Institute of North America. 127 p. . 1993. The career and disappearance of Hans K.E. Krüger, Arctic geologist, 1886-1930. Polar Record 29(171):277-304.

BERNIER, J.E. 1909. Report on the Dominion Government Expedition to the Arctic Islands and the Hudson Strait on board the C.G.S. Arctic, 1906-1907. Ottawa: Department of Marine and Fisheries. 127 p.

DICK, L. 2001. Muskox land: Ellesmere Island in the age of contact. Calgary: University of Calgary Press. 615 p.

DORION-ROBITAILlE, Y. 1978. Captain J.E. Bernier's contribution to Canadian sovereignty in the Arctic. Ottawa: Indian and Northern Affairs. $110 \mathrm{p}$.

FAIRLEY, T.C. 1959. Sverdrup's Arctic adventures. London: Longmans, Green and Co. Ltd. 305 p.

FOSHEIM, I. 1994. Storvilt, is og Nytt Land: Med polarskuta «Fram» til Nordvest-Grønland 1898-1902. Oslo: H. Aschehoug \& Co. 214 p.

GILBERG, R. 1976. Thule. Arctic 29(2):83-86.
GRANT, S.D. 2002. Arctic justice: On trial for murder, Pond Inlet, 1923. Montreal: McGill-Queen's University Press. 342 p.

JUDD, D. 1969. Canada's northern policy: Retrospect and prospect. Polar Record 14(92):593-602.

LEE, H.P. 1928. Policing the top of the world. London: John Lane The Bodley Head Limited. $250 \mathrm{p}$.

MacMILLAN, D.B. 1918. Four years in the white north. New York: Harper \& Brothers Publishers. 426 p.

ROSS, G.W. 1976. Canadian sovereignty in the Arctic: The Neptune Expedition of 1903-04. Arctic 29(2):87-104.

RCMP (ROYAL CANADIAN MOUNTED POLICE). 1929. Inspector Joy's Patrol. In: Report of the Royal Canadian Mounted Police for the year ended September 30, 1929. Ottawa: F.A. Acland. 62-71.

STALLWORTHY,H.W. 1932. Report to RCMP“HQRS” Division from the Eastern Arctic Sub-district, Bache Peninsula Detachment, June 25th, 1932. Manuscript on file at the Arctic Institute of North America, University of Calgary, Calgary, Alberta T2N $1 \mathrm{~N} 4$.

SVERDRUP, O. 1903. Nyt land: fire aar I arktiske egne. Kristiania: H. Aschehoug \& Co.

TAYLOR, A. 1955 Geographical discovery and exploration in the Queen Elisabeth Islands. Geographical Branch Memoir 3. Ottawa: Department of Mines and Technical Surveys. $172 \mathrm{p}$.

Peter Schledermann is a senior research associate of the Arctic Institute of North America. 